\title{
ENIGMA AS A LITERARY DEVICE IN NATIVE AMERICAN FOLKLORE: JAROLD RAMSEY'S ANALYSIS OF TWO CLACKAMAS CHINOOK TALES
}

\author{
Daniel J. Frim
}

\begin{abstract}
This paper discusses Jarold Ramsey's classic article, The Wife Who Goes Out Like a Man, Comes Back as a Hero: The Art of Two Oregon Indian Narratives. It analyzes Ramsey's arguments against the backdrop of Alan Dundes's work in Native American folklore as well as more recent controversies in this field. Some scholars, such as Dundes, have attempted to vindicate Native American folklore against Eurocentric criticism by fitting it into Western literary molds. Ramsey, on the other hand, brings to light the distinctive aesthetic qualities of two tales from the Pacific Northwest by recognizing the ways in which these narratives often stray from the literary expectations of Western readers. In this respect, Ramsey's approach is preferable to that of Dundes, and it provides a model for the careful, aesthetically oriented analysis of the idiosyncratic features of individual folklore traditions.
\end{abstract}

Keywords: Native American folklore, Pacific Northwest, Clackamas Chinook, Alan Dundes, Jarold Ramsey, aesthetics of folklore

Alan Dundes has described what he calls "the casualist theory of American Indian folktale composition [...] According to this view, American Indian folktales are composed of random, unstable conglomerates of motifs" (Dundes 1965: 206). Dundes rejects this approach, arguing instead that Native American folktales, like the folktales of Europe, can be mapped by logical, Proppian morphological schemes. With this argument, Dundes is attempting to rescue Native American folklore from Eurocentric criticism, ${ }^{1}$ but in doing so, he overlooks some of the distinctive qualities of this folklore tradition. In an article entitled The Wife Who Goes Out Like a Man, Comes Back as a Hero: The Art of Two Oregon Indian Narratives, Jarold Ramsey likewise responds to impressions of Native American folklore as illogical. His response, however, is more nuanced than that of Dundes. Ramsey combines basic elements of Dundes's argument with another approach, which allows the Clackamas Chinook folktales that Ramsey 
analyzes to be puzzling or even, in some respects, illogical $^{2}$, and which seeks to explain these qualities as meaningful literary devices.

Admittedly, at many points, Ramsey suggests that the most puzzling, apparently nonsensical or surreal features of Native American folklore can be cleared up through consultation of cultural, contextual knowledge, and in this respect, his argument parallels that of Dundes. For example, at the beginning of his paper, Ramsey describes traditional assessments of Native American folklore in the following terms:

Indian literature is likely to seem all the more terse, even cryptic, to us for being the verbal art of highly ethnocentric, tribal people, whose infinitely diverse cultures we still don't know much about. (1989: 210)

The implication here is that Indian lore makes little sense "to us" but that it makes perfect sense to its intended audience or, ideally, to an ethnographically informed folklorist. Similarly, Ramsey addresses one of the most mysterious motifs in the article's focal Clackamas folktale: the practice of "dancing for the head" (ibid.: 217) of a decapitated murder victim. He explains, "Presumably, the dance is intended to help the killer obtain its spirit power, as in the practice of most Western Indian groups" (ibid.: 218). This ethnographically informed explanation transforms what at first appears to be a surreal, inscrutable element of the story into a clear allusion to a Native American ritual.

Elsewhere, however, Ramsey skillfully combines knowledge of ethnographic context with a more interpretive approach that allows Native American folklore to retain some of its surreal, puzzling, or apparently illogical qualities. He addresses, for example, a plot event which lacks logical clarity because it is apparently unmotivated and is not caused by previous events in the plot: in the story Seal and Her Younger Brother, a man is murdered in his bed by his mysterious wife, but no explanation of the murder or of its motives is provided. Ramsey has the opportunity to explain away this apparent gap in the logical clarity of the tale, because he points out that the plot of Seal and Her Younger Brother also occurs as an embedded episode within another, longer story, The Revenge against the Sky People. In The Revenge against the Sky People, the embedded episode that shares its plot with Seal and Her Younger Brother receives full elucidation in the larger context of the story. Ramsey therefore acknowledges the possible contention that the mysterious Seal and Her Younger Brother is "no more than an interesting fragment" and that it is puzzling merely because it has been separated from the larger context of "the 'true version' [i.e., The Revenge Against the Sky People]" (ibid.: 216). According to this hypothetical approach, fuller knowledge of the cultural and inter-textual context of Seal and Her Younger Brother demonstrates that, in fact, this tale leaves nothing unexplained; it initially puzzles us only because it has come to 
us in an incomplete version, but its inscrutability can be remedied by a fuller knowledge of the tale's context.

However, Ramsey emphatically rejects this approach, writing: "both the impression and the conclusion would be wrong. Indian mythology, like all oral literature, relies on narrative motifs and situations that may be current in differing combinations" (ibid.). Here, Ramsey seems to acknowledge the existence of apparently "random, unstable conglomerates of motifs" perceived by the "casualist" approach that Dundes rejects (Dundes 1965: 206). But Ramsey, unlike Dundes, sees these as meaningful literary features of Native American folklore that should be analysed rather than denied. Ramsey cites Hymes, who argues that the enigmatic, murderous wife in Seal and Her Younger Brother is a typical Native American Trickster character, whose mischievous or evil acts are "an indispensable plot agent", and that "according to the conventions of the Northwest Trickster, no special purpose or provocation for killing is necessary" (ibid.: 213). In citing Hymes's analysis, Ramsey still refers to ethnographic knowledge of the tale's context, but instead of using it to deny that the motives underlying the murder episode are mysterious, he suggests that this mysteriousness is a literary, aesthetic feature of the narrative:

It is hard not to admire the narrative artistry by which means the ostensible primary action (the deception and killing of the husband by his 'wife') is muted and left obscure so as to bring the apparent secondary action [...] into the foreground. (ibid.)

Here, Ramsey admits that the tale does omit any explanation of the husband's murder, but he suggests that this omission and its impact on the logical clarity of the tale act as literary devices, whose purpose is to direct attention away from the murder and onto the tale's true focus.

Ramsey's article, which was first published in $1977^{3}$, bears upon a controversy that has grown in intensity over the past three decades. Attempts to "rescue" Native American folklore have gone far beyond the scope of Dundes's and Ramsey's arguments regarding narrative logic or other literary features and have attempted to address the daunting question of historicity. Native American folklore is now widely treated as a factual, historical document (EchoHawk 2011: 268). While few, presumably, would deny that folklore has the potential to preserve historical data, new approaches to Native American lore sometimes apply this principle of historicity to a degree that may surprise students of other folklore traditions. Roger Echo-Hawk, for example, argues that folklore can preserve memories stretching back as far as 40,000 years (ibid.: 274 ) and that the origin myths of the Arikara and other tribes record events in Pleistocene-era migrations, such as journeys through the Arctic represented by tales of "a dark origin point" (ibid.: 276). This scholarly trend represents an 
earnest and much-needed attempt to move beyond the influence of dismissive attitudes towards non-Western cultures and literatures. But in the midst of this controversy, Ramsey's article presents a nuanced argument suggesting that, without attempting to fit Native American folklore into pre-formed molds such as Proppian morphological schemes (or, perhaps, literal documentary historicity), it is possible to begin understanding this folklore tradition in its own terms through careful analysis aimed at elucidating the tradition's distinctive literary qualities.

\section{NOTES}

1 This interpretation was suggested by my colleagues Becca Harbeson and William Goulston, and confirmed by Professor Joseph Harris, in Folklore and Mythology 98a, a course at Harvard University. The use of the term "rescue" in this context is borrowed from Professor Joseph Harris.

2 By 'illogical', I do not mean self-contradictory or otherwise counter to logic. Instead, I use 'illogical' to refer to a lack of explicitly logical plot structure. In other words, for the purposes of this paper, an 'illogical' tale is one in which things happen for no explicit reason. The plotline may consist of unmotivated actions or events that do not logically lead from one to the next. Or, if the central plotline is logically structured, then auxiliary events entering or affecting the central plotline are random, spontaneous, or inexplicable. To put this feature in Levi-Strauss's terms, "it would seem that in the course of a myth anything is likely to happen. There is no logic, no continuity. Any characteristic can be attributed to any subject; every conceivable relation can be met. With myth, everything becomes possible." (Levi-Strauss 1972: 291).

3 PMLA, Vol. 92, pp. 9-18.

\section{REFERENCES}

Dundes, Alan 1965. Structural Typology in North American Indian Folktales. Alan Dundes (ed.) The Study of Folklore. Englewood Cliffs, New Jersey: Prentice Hall Inc., pp. 206-215.

Echo-Hawk, Roger C. 2000. Ancient History in the New World: Integrating Oral Traditions and the Archaeological Record in Deep Time. American Antiquity, Vol. 65. No. 2, pp. 267-290. http://www.jstor.org/stable/2694059, last accessed on March 23, 2013.

Levi-Strauss, Claude 1972. The Structural Study of Myth. In: William A. Lessa \& Evon Z. Vogt (eds.) Reader in Comparative Religion: An Anthropological Approach. Evanston: Harper and Row, pp. 289-302.

Ramsey, Jarold W. 1989. The Wife Who Goes Out Like a Man, Comes Back as a Hero: The Art of Two Oregon Indian Narratives. In: Elliott Oring (ed.) Folk Groups and Folklore Genres: A Reader. Logan, Utah: Utah State University Press, pp. 209-223. 